\title{
Democracy: History of a Crisis Without End
}

\author{
Marco Cilento \\ Professor of Political Science and Comparative Politics, \\ University of Rome - La Sapienza
}

\section{Claudio Foliti}

PhD in Political Languages and Communication, and Adjunct Professor (Lecturer) of Comparative Politics, University of Rome - La Sapienza

\section{Doi:10.5901/mjss.2016.v7n6p402}

\begin{abstract}
Over the last years it has been increasingly discussed about the crisis of democracy, a process that does not only concern the new realities, but also and perhaps more surprisingly the Western world. This crisis of the Western world seems to be at the root of the weakness of the democratic principle and the principles related to it. In particular, the following three seem to be the events of the new millennium that led to the crisis of democracy, intimately connected to the loss of the cultural supremacy of the West, the cradle of democracy: the globalization; the terrorist attacks of September 11, 2001; the economic crisis that began in 2008, which further weakened the West to the point of pushing the non-Western countries, all aiming at pursuing a health unprecedented material, to favor new political solutions than the classical liberal democracy. Accepting democracy as a concept semantically always open and, therefore, always in crisis, is the challenge awaiting the community of political scientists.
\end{abstract}

Keywords: democracy, crisis, West, globalization, cultural primacy

\section{Introduction}

In the late sixties and early seventies, liberal democracies came into obvious trouble. The waves of protest swept in the West, and especially in Europe, while the economies of the rich world were starting to slow down, affected by the oil shocks and the considerable political instability in various parts of the world. For the first time since 1945, the year of the Allied victory over Nazi-fascism, was spoken clearly of a crisis of democracy. It was clearly a crisis born in the Western democracies, in more mature and ancient regimes. Different explanations and of diametrically opposed premises were coming. Simplistically, we can reduce the debate into two options, on the left and on the right. On the left, the emblematic is the analysis of Jürgen Habermas with the Crisis of rationality in the mature capitalism ${ }^{1}$ of 1973 , while on the conservative front we find the report to the Trilateral Commission entitled The Crisis of Democracy: Report on the Governability of Democracies to the TrilateralCommission, written by Michel Crozier, Samuel Huntington and JojiWatanuki in $1975^{2}$.

According to Habermas, the crisis of liberal and capitalist democracy was not the result of an internal crisis to the regime, nor was a crisis of primary nature. The loss of legitimacy of democracy, the lack of confidence shown by the citizens against it would have been the result, above all, of an economic crisis by mechanisms inherent to capitalism itself. The governments, according to Habermas, were required to provide answers and solutions because the citizens perceived the economic crisis as a problem to be solved through political and administrative means. The most obvious solution for the administrative machinery, would have been to expand public expenditure to finance the welfare state, particularly pressed in an era of economic downturn. However, tax collection could not be increased so as not to aggravate the situation of enterprises and workers and, indeed, quite often, governments were forced to cut back on costs and services to citizens (crisis of rationality). The citizens, at this point, could have chosen: protest (voice) or

\footnotetext{
1 J. Habermas, LegitimationsproblemeimSpätkapitalismus, Frankfurt a.M, Suhrkamp, 1973; trans. it., The crisis of rationality in mature capitalism, Roma-Bari, Laterza, 1979.

${ }^{2}$ M. Crozier, S. P. Huntington, J. Watanuki, The Crisis of Democracy: Report on the Governability of Democracies to the Trilateral Commission, New York, New York University Press, 1975.
} 
withdraw from (exit) their commitment within the democratic institutions (for example, the parties) ${ }^{3}$. The liberal democratic institutions, thus, lost legitimacy (legitimacy crisis) and, according to Habermas, if a remedy to this state of affairs was not placed, this could be followed by a fourth crisis, the motivational crisis. The individual lack of confidence would have caused a fraying social cohesion around the regime and the state, causing a complete and total erosion of the support in favor of democratic principles and the capitalist system.

According to the authors of the report addressed to the Trilateral Commission, on the other hand, the crisis was endogenous to the political system itself. The problem that was at the center of their analysis, however, was not related so much with the resilience of democracies in front of the increasingly widespread discontent, but the authors wondered whether democracy was still the best way to govern a country. According to the authors, the democratic mechanism had fueled a desire for participation, which was becoming more and more massed and standartized and less manageable. The increasing participation was leading to an exasperation and a growing polarization of the political struggle. On the contrary, the emergence of individualistic culture had disjointed and pulverized the social interests, producing party fragmentation and instability of the government. For the three scholars, it was in front of an endless cycle of rising expectations, fueled by an increasingly brazen individualism and much more pressing demands of equality and participation. The numerous and diversified demands of citizens, strongly centered on the economic and social level, imposed to governments a responsiveness that they were not able to provide. Hence, according to Crozier, Huntington and Watanuki, a loss of confidence stemmed not only in the political system itself (labeled as anomic democracy), but a real delegitimation of authority.

Therefore, do we find ourselves in front of a crisis of the political system determined by external and structural factors or the one of the seventies was, however, a crisis in the democratic system, an entire political and endogenous crisis? Did the crisis appear due to a deficiency of participation arising from the interference of external power centers to the political world, or from an excess of participation? In fact, two different approaches were to collide to interpret the phenomenon of the crisis of democracy and the very meaning of the word "democracy", reopening the fault lines which had historically divided liberals and democrats, realists and idealists, descriptive visions and normative visions, formalprocedural conceptions and substantive conceptions, elitists and anti-elitists 4 .

The current crisis of democracy reproposes these divisions, but it appears to descend from elements much less tangible than the oil shocks (although some events show how impactful is still the economic element) and overloading problems. It is above all the crisis of a Western cultural supremacy, cornered by three major events that have opened and that are profoundly marking the beginning of the Third Millennium: the globalization, which has led to the weakening of the sovereignty of the States and has definitely shifted the focus of the relevant decisions from the sphere of politics to that of the economy; the terrorist attacks of 11 September 2001, which have lost that sense of security that the West believed to have forever conquered after the end of the Soviet Union; the economic crisis which began in 2008, which further weakened the West to the point of pushing the non-Western countries, all aiming at pursuing a health unprecedented material, to favor new political solutions than the classical liberal democracy.

\section{Globalization: Issues of Sovereignty and Equality}

In these first years of the new century, the free market, despite all its limitations, is peacefully perceived as the dominant economic model on a planetary scale. It is not a coincidence that the term "globalization" is becoming more widespread and easily understood in its most superficial meaning as well as in its less immediate connotations, but, indeed, which influence more on people's lives. The consequences of this phenomenon are of considerable extent and are likely to redefine the concepts and values, that in the past were thought to be once and for all.

The world, from a Commonwealth of Independent States and sovereign, has been transformed gradually into a global village, where the physical boundaries are canceled by an economy able to penetrate and captivate all spheres of human activity through its laws and its promises. The economy triumphs over politics and multilateral institutions will gradually and inexorably be replaced to national institutions ${ }^{5}$. Democracy, with its procedures and its values, is itself the

\footnotetext{
${ }^{3}$ A. O. Hirschman, Exit, Voice, and Loyalty: Responses to Decline in Firms, Organizations, and States, Cambridge, MA, Harvard University Press, 1970.

${ }^{4}$ See J. A. Schumpeter, Capitalism, Socialism and Democracy, London, Allen \& Unwin, 1954; trans. it. Capitalism, socialism, democracy, Milan, Community Editions, 1964, p. 257 e P. Bachrach, The Theory of DemocraticElitism: A Critique, Boston, Little Brown and Company, 1967, trans. it., The theory of democratic elitism, Napoli, Guide, 1974. For a critical review of the debate between elitism and anti elitism, see D. Palano, Democracy for the few. The anti-elitism legacy and challenges to democratic theory, in «Notebooks of Political Science ॥, 2015, n. 2, pg. 173-234.

${ }^{5}$ M. F. Plattner, Globalization and Self Government, in «Journal of Democracy», vol. 13, n. 3, July 2002, pg. 54-67.
} 
subject of a redefinition that promises to be painless. Two scholars, Zaki Laidi and Philip J. Costopoulos ${ }^{6}$, Two scholars, Zaki Laidi and Philip J. Costopoulos who distinguish two dimensions within which the relationship between democracy and globalization is consumed: Democracy as Procedure and Democracy as Culture. The first has to do with the rules of the game, the second with the rules of life. With globalization, democracy as a procedure manages to find spaces and ideal spreading times. The game rules require a flexible and quick learning, perfectly in line with the exaltation of the present time and immediacy. Globalization, with its tension towards the "here and now", transforms democracy into a magical cure which promises effective and efficient solutions in a short time. Democracy as a culture, however, takes a long time to grow and root and is hardly definable and, therefore, it is always relative.

Thus, democracy is freed from history and time and becomes the perfect technical solution and policy for Countries in transition. Nevertheless, in the Countries of the global South we increasingly see a growing disconnection between democracy as an electoral process and democracy as a culture, not only able to recognize and protect human rights, but also to affirm the Rule of law and to create public spaces of expression.

This disconnection is produced by a gap of a temporal nature. Democracy as a procedure may be established quickly, but democracy as a culture takes time to develop. In countries without a democratic tradition, where the inclinations of domination and armed revolt are widespread, the democratic game on conciliation and competition principles can not be imposed in a single day and this explains why so many parties proliferate, claiming to be democratic while acting in a perfectly undemocratic way?

This disjunction and cultural devaluation of historical time, however, concerns not only the Countries in transition, but also Western democracies. The progressive exaltation of individualism and individual rights has eroded the components of collective rights. The "homo democraticusoccidentalis", as Laidi and Costopoulos call it, conceives democracy more as an instrumental means to satisfy the interests and personal benefits, and no longer as a common project. If democracy does not satisfy the demands of its citizens, this becomes a pure abstraction, dramatically widening the gap between democracy understood in the formal sense and the one really lived and experienced.

Globalisation, moreover, infringe on the nation-wide spaces and erodes certain collective preferences expressed in a democratic way, when these hinder economic interests. The weakening of the sovereignty and national policies compared to the powerful incisiveness of global phenomena would require an institutional intervention on a global or continental scale able to bring order and offer certainties, but the persistence of nation states and the lack of technical solutions to achieve a cosmopolitan democracy prevent a concerted and effective response.

A question emerges clearly at this point: how is it possible that the economy, and especially the market economy, has been able to overtake so powerfully the sphere of politics? There are two possible answers: one could be defined the the Liberal, the other the Democratic, so returning to divide the two terms on which Western regimes are founded.

The liberal answer lies in the ability of the market to respond to the tastes and desires of the people, faster and better than the democracy does not know how to do, within a culture that becomes much more individualistic. The market economy, therefore, in its power to profit maximization, is thus legitimized by the majority of people, because it does not pretend to educate them or to envisage them a political or a social project, but it listens to their wishes, even though it will not anticipate them. In this sense, the citizens will no longer to be considered as members of a nation inserted into one state space, but as consumers isolated from each other and all together inserted into the Global Village ${ }^{8}$. In this view, an idea of democracy persists and has been strengthened, as a pure political procedure. The equality that it promotes is that of the opportunities, not that of the results. In this context, the fight against poverty and inequality does not constitute a politically democratic challenge because democracy is conceived primarily as a political regime, not economic ${ }^{9}$.

Conversely, the democratic response focuses on what are the negative effects that the market causes within the democracy. Precisely, what are the virtues of the market, in the democratic perspective are conceived as the source of the problem. The answer that free trade offers to the needs of individuals is clearly antithetical compared to the basic functions of democracy, ie expressing the common good and help the company to achieve both growth and equity ${ }^{10}$. However, through a continuous invasion of the field, the economy uses the politics to suit the interests of consumers and investors, thereby distorting the essence and impeding democracy to pursue those goals that no citizen could have achieved individually.

\footnotetext{
${ }^{6}$ Z. Laidi e P. J. Costopoulos, Democracy in Real Time, in «Journal of Democracy», vol. 18, n. 3, July 2002, pg. 68-79.

7 lbidem, pg. 77.

${ }^{8}$ M. Wolf, The Morality of the Market, in «Foreign Policy», September/October 2003, pg. 47-50.

${ }^{9} \mathrm{~N}$ Bermeo, Does Electoral Democracy Boost Economic Equality?, cit., p. 23. See also A. PRZEWORSKI, The Poor and the Viability of Democracy, in A. KRISHNA (ed.), Poverty, Participation, and Democracy: A Global Perspective, New York, Cambridge University Press, 2008; also available in electronic format http://politics.as.nyu.edu/docs/IO/2800/duke.pdf (accessed on January 13, 2016;.

10lbidem, pg. 40
} 
All this leaves the society unable to reach a meeting point between economic growth and resolution of social problems such as employment instability, the growing inequality and climate changes. The result is that the interests of consumers and investors almost always dominate the common interest ${ }^{11}$.

In the Democratic vision, political equality and the achievement of certain substantive objectives constitutes an interdependent variable with the economic and social equality. Without the latter, even the most minimal of democracies is likely to remain a slave of power, of the market, of the status of the individual and of classism. As long as the structural inequalities will not be uprooted, political equality will remain only a pipe dream ${ }^{12}$.

\section{The West after September 11}

For the West, the tragic events of September 11, 2001 represented an epochal turning point in a completely negative sense, not only because since that time has become noticeable an overwhelming and unexpected vulnerability of the security system, but also because from 2001 onwards a period of deep inner crisis from all points of view has begun, with obvious and disturbing reflections on the international stage. After the terrorist attacks, the theory of the clash of civilizations has received immediately a tragic acclaim, thanks to its ability to interpret - even at an early stage - some signs of the times that could only be intuited and of which, in the nineties, has intended to resize or to circumscribe the scope.

Academically (and beyond), the theory of the clash of civilizations, first, and the attack of September $11^{\text {th }}$, later, demanded an extra effort to the scholars of the policy to try to understand what could be the best policy strategy to be adopted in an international climate that the West was discovering to be much more unfavorable compared to ten years earlier, when the end of bipolarity seemed to have sealed the victory of the best political model possible. In this framework, the role of the protagonist is played by the United States, the lone superpower in a post-bipolar world which is however increasingly unipolar and multipolar at the same time (uni-multipolarity theory) ${ }^{13}$.

In practical terms, the West suffers from many internal divisions.

The first essentially relates to the level of international relations ${ }^{14}$ and the approach to be adopted.

The realism is based primarily on competition for power between states. The challenge concerned relies on the art of the interstate diplomacy (soft power) but, above all, on the military force (hard power).

Liberalism, on the other hand, is based on the belief that the enlargement of the democratic spaces and the free market, as well as the strengthening of international institutions, can spread peace and economic prosperity in the world (soft power). In this view, the military intervention (hard power) is not excluded from everything, but is just configured as extrema ratio. The key actors, not only States, therefore, but also the international organizations, governmental or otherwise, and all those enterprises driven by big economic interests.

Idealism, or constructivism, finally, promotes the power of ideas and values, taking into account the importance of local cultures and social identities. This perspective favors, therefore, the soft power compared to the hard power. The promoters of democracy, the international networks of activism and non-governmental organizations are the key players.

To clarify which are the competing visions (realism, liberalism, idealism), which are the practical strategies available (hard power, soft power), what was the vision and the strategy adopted by the West and in particular by the leader's State? Prior to 2001, almost all the most important scholars of the time declared themselves in favor of a liberal strategy, capable of mixing and keeping in balance hard power and soft power, although attributing to the interests, a slight precedence over ideals ${ }^{15}$. Albeit with different nuances, the suggestion coming from many quarters (including that of the same Huntington) was to enlarge the democratic space, but with caution, perhaps favoring the democratic progress in those states culturally and geographically closer to the West, that is to say in Latin American Catholic countries and in orthodox countries of post-communist and post-Soviet.

After 2001, the picture changed radically, the attitude of some scholars became more daring and unscrupulous, while the clash of civilization was increasingly automatically translated in a clash between the West and Islam. The same

\footnotetext{
${ }^{11}$ Ibidem, pg .42.

12 See D. Rueschemeyer, Addressing Inequality, in «Journal of Democracy», vol. 15, n. 4, October 2004, pg.76-90; W. Brown, American Nightmare: Neoliberalism, Neoconservatism, and De-Democratization, Political Theory, vol. 34, n. 6, December 2006, pg. 690-714.

13 S. P. Huntington, The Lonely Superpower, in «Foreign Affairs», vol. 78, n. 2, March/April 1999, pg. 35-49.

14 S.M. Walt,International Relations: One World, Many Theories, in "Foreign Policy», n. 110, Spring 1998, pg. 29-46J. SNYDER, One World, Rival Theories, in «Foreign Policy», November/December 2004, pg. 52-62.

${ }_{15}^{15}$ See D. Brinkley, Democratic Enlargement: The Clinton Doctrine, in «Foreign Policy», n. 106, Spring 1997, pg. 110-127. This is, inter alia, an approach that inspired the whole c.d. Clinton Doctrine (1992-2000) and whose motto was Enlarging and Exporting Democracy. 
Fukuyama ${ }^{16}$, while continuing to support the prospect of a universal democratization, attributed precisely to the Islamic world, a special capacity for resistance to the germs of modernity and democracy. In Fukuyama, therefore, modernity and democratization, unlike Huntington, were strongly intertwined, and it would be just the rejection of the first that would also cause the rejection of the second. In the perspective of the American scholar, the regimes that he apostrophized as an Islamic - fascists constituted an ideological challenge that he even considered superior to the one launched by communism, and for this very reason he deems appropriate a military intervention in Afghanistan and Iraq against Saddam Hussein in order to hand over power to a dignified and democratic regime. The basic idea in the thinking of Fukuyama drew, now, to the realpolitik that, instead, in The End of History was convincingly criticized, tracing it back to a world still perfectly placed in the stream of a history dominated by the conflict. For the new Fukuyama, no longer were just the ideals or a crisis of legitimacy to make the change, but also the use of force.

The major change of Fukuyama route takes us into a time transformed by the events preceding it, in which the work of enlargement of democratic space which therefore did not intend to to pass more just through the emulation (or contagion effect) and therefore through a passive attitude of the West, but also through an active Western policy that was not necessarily limited to the promotion of democracy activities, but which could reasonably be transformed, if necessary, in imposition ${ }^{17}$.

Next to this position, however, other more liberal sign withstood, like those carried out by Diamond and Carothers 18. However, these are rumors that for almost a decade would have been ignored.

\section{Following the 2008 Great Crisis: The West Divisions, Primacy Finished}

The contemporary world is increasingly post-American ${ }^{19}$, but we can say without fear of being wrong that the world we live in is increasingly post-Western. Not only the rest of the world is growing faster than the West, but the West is in a recession on all fronts, starting with the economic one up to the the marketplace of ideas ${ }^{20}$. We are facing the rise of the rest of the world ", in which the West has lost its economic, social and cultural leadership. The other major powers, such as Brazil, Russia, India, China and South Africa are emerging and are imposing their way of developing and their ideas ${ }^{21}$.

The West's crisis is not, however, only a relative crisis, the psychological product of a comparison with the other powers of the world. This is also an intrinsic crisis, internal, that puts in serious doubt the hypothesis of a West as the only civilization and opens the door to the possibility of having more Wests to meditate. First of all, between the two sides of the Atlantic. Already Huntington in The Lonely Superpower argued that in a uni-multipolar world, the United States would have to watch their backs from Europe and, in particular, from its driving power, the Germany. The very birth of the euro would have resulted, according to the scholar, a major challenge to U.S. hegemony 22.

The division, however, does not end just around the interests, but also around the ideals and the two diametrically opposed conceptions of democracy: especially political in the US and is focused on procedural factors, as well as economic and social, and is attentive to concrete results in Europe. Hence, it derives later a diversified strategy as well in the field of promotion of democracy, in which it is possible to distinguish between a political approach, more typically American, and a developmental approach, characteristic of Europe ${ }^{23}$. The last few years, however, it have been seen a gradual decline of Western engagement overseas, mainly due to the economic crisis that in the West was more keenly felt, and which required a substantial spending review of all items of expenditure, including military ones, and those assigned to the activities of international cooperation.

The process of internal division, however, does not only concern the West as a whole, but also the Old Continent, where it is further aggravated the gap between the Union center, ie the virtuous Countries of central and northern Europe, and its suburbs indebted, ie the countries of the South (Portugal, Italy, Greece and Spain) ${ }^{24}$. In different sectors of civil society and of the policy of these latter, is the very idea of democracy to be entered into crisis. People feel powerless the

${ }_{16}$ F. Fukuyama, Has History Started Again?, in «Policy», vol. 18, n. 2, 2002, pg. 3-7.

${ }_{17}$ P. Grilli di Cortona, O. Lanza, B. Pisciotta, Understand the policy. A comparative perspective, Torino, Utet, 2012, pg. 179-183.

${ }^{18}$ T. Carothers, PromotingDemocracy and FightingTerror, in «Foreign Affairs», vol. 82, n. 1, January/February 2003, pg. 84-97; L. Diamond, Universal Democracy, in «Policy Review», June/July 2003, pg. 3-25.

${ }^{19}$ F. Fukuyama, Is America Ready for a Post-American World?, in "New Perspectives Quarterly», Autumn 2008, pp. 42-46; F. ZaKARIA, Facing a Post-American World, in «New Perspectives Quarterly», summer 2008, pg. 7-12.

${ }^{20}$ N. Birdsall e F. Fukuyama, The Post-Washington Consensus, in «Foreign Affairs», vol. 90, n. 2, March/April 2011, pg. 45-53.

${ }^{21}$ lididem, p. 53.

22 S. P. Huntington, The Lonely Superpower, in Foreign Affairs, vol. 78, n. 2, March/April 1999, pg. 35-49.

${ }^{23}$ T. Carothers, Democracy Assistance: Political or Developmental, in «Journal of Democracy», vol. 20, n. 1, January 2009, pp. 5-19.

${ }^{24}$ I. Krastev, A Fraying Union, in «Journal of Democracy», vol. 23, n. 4, October 2012, pg. 23-30. 
same as their governments in front of the vagaries of global markets. The States seem to be progressively dispossessed of their sovereignty.

It is actually all over Europe there is a growing the distrust of the EU institutions: in the citizens of the South, the intolerance is due to painful reforms and tremendous austerity measures that they are forced to suffer for institutions hand, which are perceived as distant, technocratic and illegitimate because are unelected; the inhabitants and the Northern elites, however, in the face of the good economic performance of their countries, do not want to delegate to a very inclusive Union a sovereignty of which they are jealous. Philippe Schmitter as well expressed his view on same issue, coming to trace a plausible doomsday scenario in which the economic crisis as an opportunity to finally make EU a political union, can become a mortal danger to the euro, for the ' Union itself, and even for the democratic solidity of some of its countries 25 .

It is no coincidence that Eurosceptic movements are asserting across Europe, and not only in countries on the periphery of the Union. The Five Stars movement in Italy, the National Front in France, the UKIP in Britain, encounter a growing support from one election to the other. The Brexit is the most painful result that the European Union has ever had to endure, opening totally unexpected and unpredictable scenarios in the relatively peripherals areas of the Union, Euroscepticism came to power with the right moves as Fidesz in Hungary, and law and justice in Poland. In Greece, to Euroscepticism is founded the "strange coalition" between radical left wing party Syriza and right-wing party Anel.

All this happened because European elites have underestimated the attractiveness of the eurosceptic electorate forces. The European narrative founded on mythical slogans as "an ever closer union" or "benefits for all ${ }^{26}$ is disintegrated in front of the reality of a system which ended up creating winners and losers, debilitated by a democratic deficit that has come to de-legitimize the European project itself. The gap that was opened between ideal and real is the space within which the Eurosceptics have entered and have been able to attract people through a more fresh fiction, able to look at the substantive issues of the present, especially at work and internal security, in an age, among other things, tragically marked by an unknown wave of migration, from the entry into force of the Schengen Treaty on the free movement in Europe.

\section{The Crisis in the World}

The crisis of democracy, however, does not only concern the Western countries. The Color Revolutions and Arab Springs have constituted an extraordinary source of democratic hope, but the change which resulted has not been persistent over time, nor has it characterized as a truly democratic, demonstrating the superficial nature of their accession.

As for the Color Revolutions, the immense wealth of hopes that they had collected was literally squandered in a few years, and their leaders were soon removed (Yushchenkoin Ukraine in 2010), or their reference parties defeated (parliamentary elections in Georgia in 2012). Ethnic divisions have strongly affected the internal stability of the regimes and the integrity of each state, aggravated by tensions with the hegemonic power of the area, Russia. In Kyrgyzstan (2010) and Ukraine (2013) new revolutions pushed to flee their respective presidents. In particular, in Ukraine, after Euromaidan, a crisis was opened (or better say, an armed conflict) in the separatist regions of South-East of the country that still has not found a solution.

Krastev $^{27}$, in his bold comparison between the post-Soviet countries and the Latin American countries, has noticed how to combine the two areas both the profound aversion towards pluralism. This aversion can get the forms of populism - as happened with Chavez in Venezuela - or those of elitism - embraced by Putin in Russia. The respective models of direct democracy and directed democracy rappresentano represent more than a clash between the power of the people and the manipulative power of the elites, the two faces of the same coin that give life to those doppelganger of democracy directly attributable to illiberal democracies, ie those "democracy without freedom" referred to by authoritative scholars such as Fareed Zakaria, for the past two decades ${ }^{28}$.

Moreover, according to Krastev, would have been precisely the Color Revolutions to have generated a kind of populist connection between the Eurasian and the Latin American region, despite the great diversity of contexts. Although other authors ${ }^{29}$, despite all due caution, glimpsed in the Color Revolutions - with varying degrees of clarity (higher or

${ }^{25}$ P. C. Schmitter, A Way Forward?, in «Journal of Democracy», vol. 23, n. 4, October 2012, pg. 39-46.

${ }^{26}$ L. Topaloff, Euroscepticism Arrive. Marginal No More, in «Journal of Democracy», vol. 25, n. 4, October 2014, pg. 76-87

${ }^{27}$ I. Krastev, Democracy's "Doubles", in «Journal of Democracy», vol. 17, n. 2, April 2006, pg. 52-62.

${ }^{28}$ F. Zakaria, The Rise of Illiberal Democracy, in «Foreign Affairs», vol. 76, n. 6, November/December, 1997, pp. 22-43. In this regard, the reader is referred to $\S 2.2$. Theories of sequence, simultaneity and gradualism.

${ }^{29}$ See, for example: M. Mcfaul, Transitions from Postcommunism, in "Journal of Democracy», vol. 16, n. 3, July 2005, pg. 5-19; V. Bunce and S. Wolchik, Favourable Conditions and Electoral Revolutions, in «Journal of Democracy», vol. 17, n. 4, October 2006, pg. 5- 
lower) - a sort of overcoming the gray phase of post-authoritarian communism, according to Krastev these revolutions would not be fed, however, by a real democratic faith.

According to various formulas, therefore, the post-revolutionary disillusion was the cause or effect of internal divisions. In this context, significant was the role of international actors. Each of them has excerted pressures of various type and intensity, in order to bring the different powers on his side. However, it was Russia to establish itself as the hegemonic force in the post-Soviet area, taking advantage of several historic features and favorable contingents: the presence in each country of important ethnic divisions and / or the presence of large Russian or Russian-speaking minorities; Russian enormous availability of energy resources and the dependence of the countries concerned on these resources; its military power; the closeness and the geographical grandeur of its territory; the common belonging to the Slavic-Orthodox culture; the promise of substantial and immediate financial aid; the growing weakness of the West, unable in consistently promote their own political ideals, devoid of a coordinated foreign policy, interested but not enough to the destiny of the area, unattractive to those countries on the material benefits plan in the short and medium term.

Russia, meanwhile, has once again become one of the world's great powers and challenged the liberal model of democracy by proposing its own, that of the sovereign democracy, according to an idea born by former Deputy Prime Minister Vladislav Surkov. This is a democracy in which the state has a real authority and in which the political elite is nationalized to meet the needs of the state and national community, its values, its history, its culture and not to international appetites ${ }^{30}$. Using terms taken from Western philosophy and political science, Surkov has created a model based on vertical power, on the connection between leaders and the people more than on representation. In the sense of propaganda, it aims to reconcile "revolution and conservation," that is an economic and social growth organized with the need to stay anchored to the traditions and identity of the nation.

The power of populism fascination, rampant in several post-Soviet countries, did not spare even the most solid democracies in post-communist Central and Eastern Europe, although they have been strongly affected but also benefited by access in the European Union. In many cases, populism has become a normal condition ${ }^{31}$ which goes beyond the traditional rift left / right, in a clash between the elites, increasingly suspicious of democracy, and the masses, more and more hostile to liberalism.

However, outside the Old Continent, far more dramatic is the situation of the countries affected by the Arab Spring and definitely far more distant from democracy are the regimes that they have produced compared to hybrid regimes of the post-Soviet. To date, only Tunisia has a situation that can be defined very carefully "encouraging». After the first victory of the Islamist Ennahda party in the parliamentary elections of 2014, this was defeated by the secularist movement Appeals to Tunisia. The current grand coalition government is supported by Appeals to Tunisia, from Ennhada and the liberal forces in the country, but the most radical Islamists remain lurking inside and outside the country.

In Egypt, the victory in the first parliamentary elections obtained by the Muslim Brotherhood was strengthened by the election to President Mohamed Morsi (June 2012). The allocation of almost unlimited powers legislation, the autocratic behavior and the fear that the president and the Muslim Brotherhood could implement an Islamic revolution led to new protests (June 30,2013), which was followed by the deposition and arrest of Morsi by the armed forces. The coup d'état follows a harsh crackdown against the Muslim Brotherhood, with numerous arrests and killings and banning of the movement. Following this period of interlude, the presidential elections of May 2014 delivered the country into the hands of the chief advocate of the crackdown against the Muslim Brotherhood, Abdel Fattah al-Sisi.

In Yemen and Libya, where authoritarian leaders have fallen, and in Syria, where Assad is still struggling in its place, the clash between the supporters and opponents of their regimes produced the most violent civil wars, of which the Islamists armed movements took advantage (especially Al-Qaeda and Daesh), who were able to proliferate and prosper.

The wind of revolution has also crossed other countries, but without causing reversals of power. In Morocco, King Mohammed $\mathrm{VI}$ responded by accelerating a process of democratization already under way. In Jordan, the uprising has been weak. In Bahrain, however, the rebellion was quickly drowned in blood, whereas in Oman, the most conservative reformist demands were partially granted by the regime.

Turkey's political scene, however, is dominated by more than ten years from the Justice and Development Party (AKP, Adalet ve Kalkınma Partisı) of Recep Tayyip Erdoğan, Prime Minister and then President of a State, that from a

18; C.H. Fairbanks, Revolution Reconsiderd, in "Journal of Democracy», vol. 18, n. 1, January 2007, pg. 42-57; V. Bunce and S. Wolchik, Debating the Color Revolutions: Getting Real About "Real Causes", in «Journal of Democracy», vol. 20, n. 1, January 2009, pg. 69-73.

30 M. Massari, Russia. Democrazia Europea o Potenza Globale? In Twenty years of the Cold War, Milano, Guerini and Associates, 2009; S. Giusti, The External Projection of the Russian Federation, Pisa, Edizioni ETS, 2012.

31 I. Krastev, Is East-Central Europe Backsliding? The Strange Death of the Liberal Consensus, in «Journal of Democracy», vol. 18, n. 4, October 2007, pg. 56-63 
democratic vanguard for Islam, is slowly but gradually turning into a illiberal democracy characterized by troubling veins of religious radicalization and euroscepticism. On the other hand, however, the consensus around the President is still widespread and firmly in power. The economic successes achieved by Turkey since 2003 are his merit (similar goes for Putin in Russia). The failed coup of July 15, 2016 is proof of this.

In East Asia, the leading-country of the area, China, does not seem very willing to widen the stitches of state control over the lives of citizens, many of whom, moreover, have benefited from the impressive economic growth of the eastern Giant. However, the sharp slowdown in Chinese economic growth and the problems inherent in difficult environmental situation due to pollution and climate change could constitute two big challenges capable of putting in serious trouble the regime in Beijing. However, China's authoritarian regime is probably the biggest opponent of liberal democracy ${ }^{32}$.

In India, the largest and the "oldest" democracy in all of Asia, in the parliamentary elections of 2014, the Hindu nationalists have achieved the widest victory of the last thirty years, winning an absolute majority of seats. The victory of Narendra Modi and the BJP (Bharatiya Janata Party) threatens to transform India into a state in which the religious element and the defense of the traditions can become the priority over other needs, to ignite a clash with the important Muslim minority in the country.

The economic crisis that strongly weakened the Latin American subcontinent in the late nineties and the beginning of the years two thousand has revealed dramatically, the limits of the Washington Consensus and the purely liberal development policies pushed by the United States, causing, as a reaction, the affirmation of a populism that has had or still has its main expression in Hugo Chávez in Venezuela, Evo Morales in Bolivia, Rafael Correa in Ecuador, Daniel Ortega in Nicaragua, Manuel Zelaya in Honduras, Cristina Kirchner in Argentina, Lula in Brazil.

As for sub-Saharan Africa, in his recent study, Kennedy Ochieng 'Opalo ${ }^{33}$ has shown that democratization through elections has given rise to two opposing trends and, therefore, two Africas: one in which the elections contribute to enlarge the democratic political space and the competition between parties; the other, on the other hand, in which the elections are used by authoritarian and semi-authoritarian regimes to legitimize stay in power. In complex social and ethnic contexts, such as that of Nigeria, for example, an increase as regards to the openness and competitiveness of elections may even overheat the tensions and create further conflict, in line with what is claimed by other authors in previous years.

This difficult context has been widely discussed in recent years, especially in the pages of the Journal of Democracy by notoriously optimistic scholars as Marc F. Plattner, Larry Diamond, Philippe Schmitter, Steven Levitsky and Lucan Way ${ }^{34}$. Some general trends can be traced.

1. The number of democracies is not substantially increased or decreased in recent years, although there are signs of a worrying tiredness and a subtle erosion towards hybrid forms. Even in the West, a weakening of confidence of citizens towards democracy is beeing experienced.

2. In democratic regimes, complete or defective, street protests are increasingly being used, but they are empty protests, based on negative coalitions, which railed against the political system, against the establishment, against the elites, against the market. These hardly lead to any appreciable result, without a significant leadership or parties of reference, nor revolutionary (because they are deprived of a project, of an ideal, an ideology), nor reformist (they do not seek a change by putting pressure on institutions, inside or outside) ${ }^{35}$.

These sad revolutions, however, do not come without a good reason. Citizens have the feeling that the elections are a tool that is losing significance, utility and incisiveness in their lives. The protest seems to return to the participants this ability to improve the state of things and the living conditions, despite the lack of a clear idea of a plausible alternative.

The peaceful protest, therefore, has become the medium that has replaced the violent insurgency but, like the latter, making the citizens conscious of their own strength and their own consistency far more than elections do. The protest, in its spontaneity, is against the elites, but does not intend to overthrow the power at all costs, just push governments to change. Translated: the citizens, abandoned the consumer role, realizing that a formal conception of democracy is no longer sufficient. Regarding the regime, citizens demand answers about

32 M. F. Plattner, The End of the Transition-Era?, in «Journal of Democracy», vol. 25, n. 3, July 2014, pg. 5-16.

${ }^{33} \mathrm{~K}$. Ochieng' Opalo, African Elections: Two Divergent Trends, in «Journal of Democracy», vol. 23, n. 3, July 2012, pg. 80-93.

${ }_{34}$ M. F. Plattner, The End of Transition-Era, cit., pg. 5-16; L. Diamond, Facing Up to the Democratic Recession, in "Journal of Democracy», vol. 26, n. 1, January 2015, pg. 141-156; P. C. Schmitter, Crisis and Transition, But Not Decline, in "Journal of Democracy», vol. 26, n. 1, January 2015, pp. 32-44; S. Levitsky and L. WAY, The Myth of Democratic Recession, in "Journal of Democracy», vol. 26, n. 1, January 2015, pg. 45-58.

${ }_{35}$ I. Krastev, From Politics to Protest, in «Journal of Democracy», vol. 25, n. 4, October 2014, pg. 5-19. 
the concrete problems of everyday life.

3. Democratic transitions of the future, just as they show the latest trends and as it has been in the past as well 36 , will be initiated mostly by a revolution from below rather than from a need to reform from above, although there will be important and decisive contributions of elites (authoritarian or opposition) in defining the goals, channeling the impulses coming from civil society and ordering policy priorities to be pursued.

4. Clearly, it is impossible to deny the importance of the action of internal actors involved in policy-making. We are witnessing, however, a renewed and increasing attention to structural variables and the constraints coming from outside, especially on the part of those international actors with whom is not shared only a geographical space, but also a cultural identity. Despite the structural factors do not appear to constitute in themselves absolute preconditions for democracy, a general democratization theory must be able to incorporate, paradoxically, also a certain dose of relativism, trying to investigate which independent variables have facilitated or complicated (conditions), but also allowed or prevented (preconditions), the democracy in certain reality-state, more or less homogeneous areas or epochs ${ }^{37}$. Obviously

In the methodological sense, scholars will be called with increasing force to combine the comparison and theoretical speculation with a more concentrated study of individual areas or even to individual cases and attentive to the suggestions that can come from a more accurate empirical analysis.

5. Democratic transitions of the future would go towards shores and new conceptions and completely unexpected. This is not to exceed the procedural definition, but to incorporate it within a larger vision. If the concern is that of becoming more prescriptive and less descriptive, the problem does not arise: today the citizens of the world are clearly aware and live the failure of any purely procedural conception, demanding democracy substantive answers to essential issues in their lives. A good democracy is one that manages to incorporate and combine formal procedure, substance and responsiveness to its citizens' questions ${ }^{38}$. To insist on crushing of the concept of democracy in low-procedural sense, under a false pretense of description, risks being transformed paradoxically in an exercise of prescription of a model today no longer considered sufficient. In this sense, the concept of democracy proves to be a more open concept, changing semantically ${ }^{39}$. If the concern of political science is to describe, not to prescribe, then its cultural resources should be channeled towards this effort of welcoming the new and ever-changing.

The variety of democracies that can result from such a composite picture can be found, according to Youngs ${ }^{40}$, the right hook on what he called liberalism-plus, on a growth of liberalism, rather than on his dreaded decline, giving new and more sap to the principles of tolerance, participation and transparency. In this sense, perhaps, would be more accurate to speak of democracy and liberalism-plus. In this regard, Youngs identifies five axes of democratic variability (Varieties of Democracy or V-Dem):

1. Greater attention to community ideals, especially those pertaining to religious morality, next to the protection of individual rights.

2. Greater participation in decisions on economic reforms, according to less hierarchical dynamics compared to that in the neo-corporatist systems.

3. Providing quotas for minorities enabling them to have voice in the political arena and to stay away from the tyranny of the majority. Youngs recommends, however, not to stop the purely formal and institutional aspects, but to promote more liberal forms of communalism, which enhance even more the grassroots participation and respond in real time to the needs of a complex and evolving society.

4. Adopt alternative forms of activism and representation (for example, forms of deliberative or participatory democracy from below, including through new technologies), but without sacrificing the typical tools of liberal and representative democracy (political parties and parliaments).

5. Create legal systems where the formal element, of typically Western origin, cooperate with the informal-

\footnotetext{
36Just as supported by Fukuyama in L. Diamond, F. Fukuyama, D. L. Horowitz, M F. Plattner, Reconsidering the Transition Paradigm, in «Journal of Democracy», vol. 25, n. 1, January 2014, pg. 86-100.

${ }^{37}$ See G. Nodia, The Revenge of Geopolitics, in "Journal of Democracy», vol. 25,n. 4, October 2014, pp. 139-150; S. LEVITSKY e L. WAY, Structure vs. Choice, in «Journal of Democracy», vol. 25, n. 4, October 2014, pg. 151-156; R. KAGAN, The Weight of Geopolitics, in «Journal of Democracy», vol. 26, n. 1, January 2015, pg. 21-31.

${ }^{38}$ L. MoRLINO, Democracy and democratization, Bologna, II Mulino, 2003; L. DIAMOND and L. MORLINO, The Quality of Democracy: An Overview, in «Journal of Democracy», vol. 15, n. 4, October 2004, pg. 20-31

${ }^{39}$ A. Mastropaolo, Democracy, neo-democracy, post-democracy: three paradigms in comparison, Comparative Public Law and European, vol. 4, 2001, pg. 1612-1635

${ }^{40}$ R. Youngs, Exploring Non-Western Democracies, in «Journal of Democracy», vol. 26, n. 4, October 2015, pg. 140-155.
} 
traditional element, characteristic of some countries where legal issues are usually judged by tribal chiefs or village heads.

Realizing that there may be different types of democracy and that the concept today experience a liquidity never experienced before, ca we be protected from the possibility of collapses or democratic erosions? Can the new democracies (but also the oldest ones) feel safe in a world now devoid of safe havens towards which they can navigate and land? To answer this last question we can refer to the speech given by Guillermo O'Donnell at the Triennial World Congress of Political Science held in Fukuoka in 2006, during which he has been awarded the LifetimeAchievement Award of the International Political Science Association. The speech was then transcribed and published in the Journal of Democracy in the January edition of 2007 and suggestively titled The PerpetualCrisis of Democracy ${ }^{41}$.

His speech starts with three key points: there is not an unanimous agreement on the meaning of the word "democracy"; there have never been so many democratic regimes (at least formally) as there are now and there have never been so many rulers ready to declare that theirs is a democratic regime as it is now; Today, all regimes derive their legitimacy from popular support, which is expressed through free voting procedure. Even in cases where the actual pattern of the regime differs from the democratic form, the War of Ideas was won by the principle of popular sovereignty, and that is what makes democracy a powerful tool.

According to an authoritative scholar, therefore, all democracies, from the worst to the most advanced, are called to a burdensome and important task: «because they are democracies, they can and should improve» 42 .

The blessing and the curse of democracy lies in the fact that this, as it is related to the size of which has been discussed and to the recognition of human dignity in all its aspects, is irrevocably characterized by the presence of an increasingly open horizon, which continuously generates hopes and frustrations, which rejects authoritarianism but also every ethnocentric form of reaching the end of history. For these reasons, democracy is set up as an semantically open object, never concluded, whose crisis is nothing but a sign of an eternal absence.

We must consider that democracy is and always will be in some kind of crisis: It is constantly redirecting its citizens' gaze from a more or less unsatisfactory present toward a future of still unfulfilled possibilities. This is because democracy is more than a valuable kind of political arrangement. It is also the often notorious sign of a lack. It is the perpetual absence of something more, of an always pending agenda that calls for the redress of social ills and further advances in the manifold matters which, at a certain time and for a certain people, most concern human welfare and dignity. This is why the meanings of democracy are so protean, and always essentially contested. It is also why the theoretical and empirical analyses that we frame as social scientists should take into account these constantly varying and contested meanings ${ }^{43}$. [...] Many democracies are in crisis, though the crises vary as to depth and specific characteristics. Still, there is in these crises something that belongs to what is best and most distinctive about democracy. For the crises underline democracy's intrinsic mix of hope and dissatisfaction, its highlighting of a lack that will never be filled44.

\section{References}

A. Mastropaolo, Democracy, neo-democracy, post-democracy: three paradigms in comparison, Comparative Public Law and European, vol. 4, 2001, pg. 1612-1635

A. O. Hirschman, Exit, Voice, and Loyalty: Responses to Decline in Firms, Organizations, and States, Cambridge, MA, Harvard University Press, 1970.

C.H. Fairbanks, Revolution Reconsiderd, in «Journal of Democracy», vol. 18, n. 1, January 2007, pg. 42-57;

D. Brinkley, Democratic Enlargement: The Clinton Doctrine, in «Foreign Policy», n. 106, Spring 1997, pg. 110-127. This is, inter alia, an approach that inspired the whole c.d. Clinton Doctrine (1992-2000) and whose motto was enlarging and Exporting Democracy.

D. Palano, Democracy for the few. The anti-elitism legacy and challenges to democratic theory, in «Notebooks of Political Science », 2015, n. 2, pg. 173-234.

D. Rueschemeyer, Addressing Inequality, in «Journal of Democracy», vol. 15, n. 4, October 2004, pg.76-90;

F. Fukuyama, Has History Started Again?, in «Policy», vol. 18, n. 2, 2002, pg. 3-7.

F. Fukuyama, Is America Ready for a Post-American World?, in «New Perspectives Quarterly», Autumn 2008, pp. 42-46; F. Zakaria, Facing a Post-American World, in «New Perspectives Quarterly», summer 2008, pg. 7-12.

F. Zakaria, The Rise of Illiberal Democracy, in «Foreign Affairs», vol. 76, n. 6, November/December, 1997, pp. 22-43. In this regard, the reader is referred to $\S 2.2$. Theories of sequence, simultaneity and gradualism.

${ }^{41}$ G. O'Donnell, The Perpetual Crisis of Democracy, in «Journal of Democracy», vol. 18, n. 1, January 2007, pg. 5-11.

42/bidem p. 9.

${ }^{43}$ Ibidem.

44 Ibidem, p. 10. 
G. Nodia, The Revenge of Geopolitics, in «Journal of Democracy», vol. 25,n. 4, October 2014, pp. 139-150;

G. O'donnell, The Perpetual Crisis of Democracy, in «Journal of Democracy», vol. 18, n. 1, January 2007, pg. 5-11.

I. Krastev, A Fraying Union, in «Journal of Democracy», vol. 23, n. 4, October 2012, pg. 23-30.

I. Krastev, Democracy's "Doubles", in «Journal of Democracy», vol. 17, n. 2, April 2006, pg. 52-62.

I. Krastev, From Politics to Protest, in «Journal of Democracy», vol. 25, n. 4, October 2014, pg. 5-19.

I. Krastev, Is East-Central Europe Backsliding? The Strange Death of the Liberal Consensus, in «Journal of Democracy», vol. 18, n. 4, October 2007, pg. 56-63

J. A. Schumpeter, Capitalism, Socialism and Democracy, London, Allen \& Unwin, 1954; trans. it. Capitalism, socialism, democracy, Milan, Community Editions, 1964, p. 257 e P. BACHRACH, The Theory of Democratic Elitism: A Critique, Boston, Little Brown and Company, 1967, trans. it., The theory of democratic elitism, Napoli, Guide, 1974.

J. Habermas, Legitimations problemeim Spätkapitalismus, Frankfurt a.M, Suhrkamp, 1973; trans. it., The crisis of rationality in mature capitalism, Roma-Bari, Laterza, 1979.

K. Ochieng' Opalo, African Elections: Two Divergent Trends, in «Journal of Democracy», vol. 23, n. 3, July 2012, pg. 80-93.

L. Diamond, F. Fukuyama, D. L. Horowitz, M F. Plattner, Reconsidering the Transition Paradigm, in «Journal of Democracy», vol. 25, n. 1 , January 2014, pg. 86-100.

L. Morlino, Democracy and democratization, Bologna, II Mulino, 2003; L. DIAMOND and L. MORLINO, The Quality of Democracy: An Overview, in «Journal of Democracy», vol. 15, n. 4, October 2004, pg. 20-31

L. Topaloff, Euroscepticism Arrive. Marginal No More, in «Journal of Democracy», vol. 25, n. 4, October 2014, pg. 76-87

M. Crozier, S. P. Huntington, J. Watanuki, The Crisis of Democracy: Report on the Governability of Democracies to the Trilateral Commission, New York, New York University Press, 1975.

M. F. Plattner, Globalization and Self Government, in «Journal of Democracy», vol. 13, n. 3, July 2002, pg. 54-67.

M. F. Plattner, The End of the Transition-Era?, in «Journal of Democracy», vol. 25, n. 3, July 2014, pg. 5-16.

M. F. Plattner, The End of Transition-Era, cit., pg. 5-16; L. Diamond, Facing Up to the Democratic Recession, in «Journal of Democracy», vol. 26, n. 1, January 2015, pg. 141-156;

M. Massari, Russia. Democrazia Europea o Potenza Globale? In Twenty years of the Cold War, Milano, Guerini and Associates, 2009;

M. MCFAUL, Transitions from Postcommunism, in «Journal of Democracy», vol. 16, n. 3, July 2005, pg. 5-19;

M. Wolf, The Morality of the Market, in «Foreign Policy», September/October 2003, pg. 47-50.

N Bermeo, Does Electoral Democracy Boost Economic Equality?, cit., p. 23. See also A. Przeworski, The Poor and the Viability of Democracy, in A. Krishna (ed.), Poverty, Participation, and Democracy: A Global Perspective, New York, Cambridge University Press, 2008; also available in electronic format http://politics.as.nyu.edu/docs//O/2800/duke.pdf (accessed on January 13, 2016).

N. Birdsall e F. Fukuyama, The Post-Washington Consensus, in «Foreign Affairs», vol. 90, n. 2, March/April 2011, pg. 45-53.

P. C. Schmitter, A Way Forward?, in «Journal of Democracy», vol. 23, n. 4, October 2012, pg. 39-46.

P. C. Schmitter, Crisis and Transition, But Not Decline, in «Journal of Democracy», vol. 26, n. 1, January 2015, pp. 32-44;

P. Grilli DI Cortona, O. Lanza, B. Pisciotta, Understand the policy. A comparative perspective, Torino, Utet, 2012, pg. 179-183.

R. Kagan, The Weight of Geopolitics, in «Journal of Democracy», vol. 26, n. 1, January 2015, pg. 21-31.

R. Youngs, Exploring Non-Western Democracies, in «Journal of Democracy», vol. 26, n. 4, October 2015, pg. 140-155.

S. Giusti, The External Projection of the Russian Federation, Pisa, Edizioni ETS, 2012.

S. Levitsky and L. Way, The Myth of Democratic Recession, in «Journal of Democracy», vol. 26, n. 1, January 2015, pg. 45-58.

S. Levitsky e L. Way, Structure vs. Choice, in «Journal of Democracy», vol. 25, n. 4, October 2014, pg. 151-156;

S. P. Huntington, The Lonely Superpower, in «Foreign Affairs», vol. 78, n. 2, March/April 1999, pg. 35-49.

S. P. Huntington, The Lonely Superpower, in Foreign Affairs, vol. 78, n. 2, March/April 1999, pg. 35-49.

S.M. Walt, International Relations: One World, Many Theories, in «Foreign Policy», n. 110, Spring 1998, pg. 29-46J. Snyder, One World, Rival Theories, in «Foreign Policy», November/December 2004, pg. 52-62.

T. Carothers, Democracy Assistance: Political or Developmental, in «Journal of Democracy», vol. 20, n. 1, January 2009, pp. 5-19.

T. Carothers, Promoting Democracy and Fighting Terror, in «Foreign Affairs», vol. 82, n. 1, January/February 2003, pg. 84-97; L. Diamond, Universal Democracy, in «Policy Review», June/July 2003, pg. 3-25.

V. Bunce and S. Wolchik, Debating the Color Revolutions: Getting Real About "Real Causes", in «Journal of Democracy», vol. 20, n. 1, January 2009, pg. 69-73.

V. Bunce and S. Wolchik, Favourable Conditions and Electoral Revolutions, in «Journal of Democracy», vol. 17, n. 4, October 2006, pg. 5-18;

W. Brown, American Nightmare: Neoliberalism, Neo-conservatism, and De-Democratization, Political Theory, vol. 34, n. 6, December 2006, pg. 690-714.

Z. Laidi e P. J. Costopoulos, Democracy in Real Time, in «Journal of Democracy», vol. 18, n. 3, July 2002, pg. 68-79. 